\title{
Policies in the Fight against Fiscal Evasion in Albania
}

\author{
Henris Balliu LL.M \\ Pedagogue at Faculty of Justice, University of Tirana, Albania
}

\begin{abstract}
The transition process in Albania has revealed numerous problems uniformly spread having versatile impact. Such referring point is quality and effectiveness of fiscal policy in order to establish a sustainable connection among its goals and instruments being used. As a country that operates under conditions of market economy, Albania deems it necessary to increase the level of revenues in order to stabilize problems of economic balance and balance of payments. The analyses have shown that authority of fiscal policy has played primary role in the economic progress of the country. For that purpose, the behavior of contributors and their opportunity for evasion is taken into account as an important factor in the drafting of fiscal policies. The large business and VIP business conceal revenues; manipulate balances and the number of employees. Therefore they avoid tax liabilities. Roughly $45 \%$ of economy in the country is informal, an informal market, an informal business and so on. Even nowadays, when a series of measures and amendments to the law have taken place, we still remain inside the transition train toward the station of a country with European standards. That is why the goal of this work is to analyze the offense of fiscal evasion and evasion of tax liabilities, the instruments in the prevention of this offense and the bodies rendering assistance in the fight against fiscal evasion. Arising questions are as following: What is the meaning of fiscal evasion?; What are the forms of fiscal evasion?; What are the established structures in the fight against tax informality?; What are the strategies used in the fight against fiscal evasion?; What are the solutions that can be offered?
\end{abstract}

Keywords: fiscal evasion, informality, instrument, prevention, strategy

Introduction

Fight against fiscal evasion in Albania

1.1 Fight against informality and issues caused by illegitimacy in Albania

The large business and VIP business conceal revenues; manipulate balances and the number of employees. Therefore they avoid tax liabilities. Roughly 45 per cent of economy in the country is informal. Amendments taking place on daily basis by Parliamentary Law Commission appear to eradicate the gangrene caused by informality.

If tax on tobacco is collected and you sell less tobacco, that constitutes tax evasion. If you fail to report the sales of tobacco directly to the government, then it is fiscal evasion. The tax evasion is not a new issue even though in the recent years the tax evasion has attracted particular attention of the wide public. ${ }^{1}$

Not only recently but for many years in turn we have heard about the fight against informality. Informal market, informal business and so on. Even nowadays, when a series of measures and amendments to the law have taken place, we still remain inside the transition train toward the station of a country with European standards.

We live in a free market economy reliant on free and fair competition where there exists a regulator, which imposes rules and laws. The arising question is who wins? What weapons do they use, how do they defend themselves? The truth is that every day we face problems that are as familiar as they are new as a chain reaction. The concealment of revenues from businesses, from the smallest to the largest ones is not new but concealement patterns are new. The declarations regarding tax on profit only to justify the level of expenditures are the most

${ }^{1}$ E VAN GAMEREN, The internal economics of firm An investigation into the labour mobility within firms 
common cases we encounter. For instance, according to INSTAT public data only in 2014 there should be cashed four billion dollars from the value added tax in the state budget. If we subtract 4 per cent of this value, given that they belong to that part exempted from the tax we would again produce a very good figure. But the truth is that expectancy for the current year is merely 1.2 billion dollars. That is because only 8.5 per cent of this tax is collected, accordingly less than half of what should be in reality ${ }^{1}$.

In this fight the government plays the important role of the arbitrator. By means of rules and laws it imposes, it enables well-functioning for each actor in his workplace. Are these rules and laws appropriate for implementation in various time segments, how are these rules implemented, what are the penalties, is the "actor" sensitized that their implementation will increase the welfare index? All these answers deserve to have a reply. The noncompliance with these rules and laws from individuals, businesses and companies has already led to the phenomenon of informality of economy or "shadow economy" as they say which is eroding economy. Our economy has long been affected by that disease that is becoming chronic. We must do out utmost that employers and employees not be participants in violations and concealments. The big truth is that tax inspectors themselves are inspiring this phenomenon. As long as tax inspectors are frequently replaced and fail to offer high level of professionalism, moreover becoming participants in the non-compliance with the laws we shall continue to have such problems.

\section{The common patterns of informality discovered by foreign audits:}

All actors must implement imposed laws and rules, but we notice businesses that exercise unregistered activities, therefore concealing their revenues, other businesses that lack documentation for their economic activities and some others that present fictious documentation. We are all aware of the existence of two balances. Moreover, both balances "are legitimate" given that they declare only the level of expenditures. The use of the cash register constitutes a step forward, but we often encounter its closure and its registration as to only the value of expenditures and very few profits. Therefore the tax on profit is concealed. The banks would render a huge contribution if they would conduct necessary inspections before

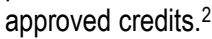

The fact they accept any kind of submitted balance-sheets of a very high performance without conducting verifications of departments or tax authorities has enabled abusers to submit ready-made balances in exchange for money. How responsible are banking institutions on the granting of credits as to acceptance of these fictious balances?! It is merely this fraud, this informality that has triggered the existence of a market, of financial capitals, non-activation of the stock exchange, the non-listing of companies in the market and malfunctioning of this market that would activate many capitals of the economy of this country and would serve as oxygen for economy. That would be made possible in order that Albanian businessmen would not just remain content to the extent of being "shopkeepers", content only with cash, but in order that they could use financial policies of the European world where we wish to be.

The audit of authorized experts has the right to check all those businesses with an annual turnover above ALL 30 million with personnel of over 30 employees, therefore the large business. It is concerning because you observe it in concealments, concealment of revenues or concealment of the number of employees even in those companies that are very powerful with satisfactory marketing campaigns. We also call them VIP companies. The middle-sized and small-sized businesses can be audited through balances they prepare and submit. It occurs often that according to balances they submit, they appear as businesses with losses for more than two years. These are very strong signals to be taken into consideration and to be investigated by tax inspectors for tax evasion.

The problem of the labor market is another source of informality of economy. The formal labor contracts, undeclared employment or as we call it illegal work, declaration of non-real revenues, all these actions among employers and employees who conceal revenues that would be addressed to the development of the economy bring about the opposite effect. These kind of activities enrinch not only individuals, but they risk and increase insecurity of an employee who can lose his job for any kind of reason. I bring to your attention the sensitization of individuals capable to work who enter a labor relationship, the importance of what is called labor contract. Assessing it is based on the labor code prior to the start of a work in order to be self-protected in the first place. The government policies on employment, the opening of employment

1Data on state budget INSTAT, 2014

2 Data from External Audit Inspectorate Tirana ,May 2016 
offices, the existence of private employment centers is a positive step to render the labor market mostely functional that operates according to request and offer on various professions.

"The illegal work" along with the informal work is part of the so-called "uncontrolled economy" The decision to conceal an activity can stem from many factors:

The activity is held under conditions of fiscal evasion (VAT, taxes etc)

The activity avoids social insurance contributions, avoids legal normatives or fails to comply with norms on work schedule, minimum salary etc.

The activity lacks necessary administrative authorizations to be held.

The illegal economy is a complex of production activities, service activities and use of productions and services, which avoids openly statistic registrations. This category includes the so-called illegal work such as unpaid work of unemployed people, retired people, households, students, second undeclared employment.

A particular kind of illegal concealed economy is also criminal economy, which includes all kinds of illegal activities such as: smuggling, prostitution, gambling, sale of drugs, organized thefts. The concealed economy and illegal work create a system, a deformity in statistics directly proportional to its relative size, which render the analysis of real economic situation less accurate. The Albanian labor market has suffered big changes after 1991; the economic transformation has caused essential changes in the structure of production and employment sectors.

The development of private sector runs parallel to informalization of economy in general and illegal work in particular. The hidden economy has existed since the approval of the law that regulates labor relations. All transition societies pass through this phenomenon of labor market where in certain period relations between legal economy and illegal economy change.

The economic activity of informal sector cohabits with structured sector where it competes successfully in several cases. There are evident cases when informal sector supplies producing activities with raw material and furnishes with ready products in the market. The transition period lived by the Albanian state has created spaces for the flourishing of informal market, which amounts to considerable values in other Southeastern European countries as well. In general the social partnets have assesses consequences of illegal work market in the economic, fiscal and social regard, whereas these consequences bear in themselves the deficit in the state budgert, decrease of revenues in social insurance contributions, fiscal evasion with regard to tax on profits as well as establishment of an unprotected social class.

The sectors of economy where illegal employment faces relatively higher levels are as following:

-The sector of construction

-The small-sized and middle-sized production

-The sector of services

-The transport

-The trade

-The private fishing activity etc

The labor state administration tackles with preparation, administration, audit and review of national labor policy.

Within the framework of this administration the Labor State Inspectorate as its constituent part must play an important role in the minimization of the illegal work.

\section{Efforts to minimize illegal work are accomplished in three regards:}

Registration of economic subjects accompanied with declaration of evarage work power.

Permanent inspections of subjects in order to provide continous implementation of labor legislation 
Organization of joint national actions on audit of labor market in various sectors of economy renders priority to construction sector for the mere nature of its labor.

Organization of audits brings about concrete results in the finding of:

-Unlicensed self-employed merchants

-llegal economic activities

-Legal economic activities

-Economic activities with non-renovated fiscal documentation

-Undeclared economic activities to Health Insurance Institute

-lllegal employment rate

-Self-employed people in the free market

One of the sectors where non-implemenattion of legislation is more tangible is the construction sector and production of construction material. This sector is assessed as following:

An activity that can be exercised anywhere without conditioned geographic limitations.

A profitable activity under the conditions of today's market economy with premises for fiscal evasion related to fictious declarations of revenues on employment and failure to cash insurance contributions.

One of the most endangered sectors prone to accidents at work. Attention is mainly focused on the following:

Highlighting licensed subjects and discovery of illegal activities in construction and production of construction material.

Highlighting measures taken to the implementation of labor legislation on protection and safety at work as well as social protection.

Control on labor market and distribution of labor force according to districts and important activities in the economy of the country.

The construction sector and production of construction material as one of the most important sectors of economy and national production plays an important role in the increase of revenues per capita of the population, given that it involves an important active labor force that is why it is work priority not only during the year but also in national actions engaging a substantial number of employees.

Despite the large number of small-sized enterpreneurships in construction that render it difficult to control this labor market, we must take into account that organization of trade unions in this sector is relatively low.

The responsibility on huge proportions of illegal work in the construction sector is joint:

-The government does not provide in appropriate fashion the implementation of legislation related to requirements of liabilities from employers or businesses in this sector.

-Employers also bear a huge responsibility given that they fail to declare, they fail to submit necessary data on construction sector and to the detriment of employees and the government they conceal revenues generated from labor in this sector. In the event of requests made by employers they abuse with social problems of the country threatening employees with discharge from work

-Despite these difficulties employees must increase their requests in order to be organized in trade unions.

This improper functioning as to organization of trade unions in this sector makes it difficult to control the labor market.

Why does this market fail to function and how helpful are penalties and punishments in the market system?! 
As every disease is treated, the doctor or the regulator STATE must deal with the finding of cases and their fighting in order that the desease not pass in the epidemic status and not deal only with the treatment of consequences, but also with punishments. The more measures are tightened, the more corruption among those persons requesting implementation of the law and therefore this disease only advances.

\subsection{Fiscal evasion in Albanian legislation}

\section{What does the Criminal Code provide:}

\section{Article 180}

\section{Concealment of revenues}

The concealment of revenues ${ }^{1}$ or avoidance of the payment of tax liabilities through non-submission of documents or nondeclaration of necessary data according to legislation in force, the submission of forged documents, fake declarations or information with the purpose of material profit for oneself or for others by means of inaccurate calculation of the amount of taxes or contribution constitutes a criminal offense and is punishable with penalty or imprisonment up to three years.

When this offense is committed with the purpose of concealment or avoidance from the payment of a tax liability with a "higher" value than ALL 5 million it is punishable with two up to five years imprisonment.

When this offense is committed with the purpose of concealement or avoidance from the payment of a tax liability with a higher value than ALL 8 million it is punishable with four up to eight years imprisonment.

\section{Article 181}

\section{Non-payment of taxes and tariffs}

The non-payment of taxes and tariffs within the specified deadline despite the ability to pay them by the person against whom the administrative measure has been taken previously for this purpose is punishable with penalty or imprisonment up to three years. ${ }^{2}$

\section{Article 181/a}

\section{Non-accomplishent of duties by tax bodies}

The failure to accomplish duties related to collection within the specified legal deadline of taxes and tariffs by employees of the tax bodies and other official persons in charge of these duties, when done due to their fault and costs the government a damage in the value lower than ALL 1 million is punishable with penalty up to ALL 2 million; when the value is higher than ALL 1 million is punishable with 3 up to 10 years imprisonment.

\section{Article 182}

\section{Alteration in measuring devices}

The alteration or intervention in measuring devices and cash registers that issue vouchers or the use of altered devices and cash registers or allowance of use by others of irregular devices and cash registers in order to avoid full payment of taxes constitutes a criminal offense and is punishable with penalty or with imprisonment up to two years. ${ }^{3}$

\section{Article 182/a}

\section{The damage of blocking signs or suspension of commercial activity}


The deliberate damage of distinctive signs placed by the tax administration on blocking or suspension of commercial activity or the exercise of commercial activity after the notification of decision of tax administration on its blocking or suspension, constitutes criminal offense and is punishable with penalty or imprisonment up to one year. ${ }^{1}$

\section{What is stipulated by the tax legislation:}

\section{Law No. 9920 "On tax procedures in the Republic of Albania ", as amended}

\section{Article 116}

"Tax evasion"

The concealment or avoidance from payment of tax liabilities through non-submission of documents or non-declaration of necessary data according to legislation in force, the submission of forged documents or fake declarations or information that leads to inaccurate calculation of the amount of taxes or contribution constitute tax evasion and is punishable with penalty equal to 100 per cent of the difference of the calculated amount from the one that should be in fact.

Pursuant to item 1, of this article, we consider also those taxpayers who commit tax evasion by means of concealing revenues with the purpose of concealment or avoidance from payment of tax liabilities, who are found to have committed these offenses and against whom administrative sentences have been applied in accordance with:

item 1 , of article 119, of this law,

item 3, article 121, of this law;

item 1, letter "a" e "b", of article 122, of this law".

\subsubsection{Structures assigned by law to fight fiscal evasion:}

1- Structures of the Investigation Department of Economic Crime at the State Police (Sectors of Investigation of Economic and Financial CVrime at the Investigation Department of Economic and Financial Crime and Local Police Departments). ${ }^{2}$

2-Strutures of General Directorate of Taxation

Structures of Tax Investigation Department,

Structures of Tax Audit Department,

Structures of Internal Investigation Deparment, Anticorruption.

3- Structures of General Prosecution Office.

Department of Task Force at the General Prosecution Office.

Sectors of Task Force of prosecution offices at first instance courts.

Cooperation among these structures, enhancement of quality and professionalism of human capital employeed in these institutions constitutes also the key in the fight against fiscal evasion.

\section{Recommendations}

\section{Concrete measures in the fight against informality and fiscal evasion}

The fight against fiscal evasion remains yet a fight to be won by state bodies and fair businesses, mainly in these regards:

Reduction of payments in cash in the private and public sector and their channelling in the banking system since 2008 Improvement of fiscal legislation and reduction of tax instances considered as promoters of formalization 
Enhancement of effectiveness of administration through implementation of ethics and transparence of the actions of administration

Installation of electronic services for taxpayers from the moment of registration until the declaration of activity reducing time and enhancing transparence

Enhancement of providing information mainly through creation of information and service portals with effects in the reduction of time and cost of service as well as increasing transparence and limiting corruption in these services

Announcement of fiscal amnesty with the main purpose of uncovering informality throughout the Albanian economy within the country and revenues abroad

Improvement of acting agents in the labor market and capital

The state policies related to tax laws and taxes that actors must pay the government must be such as to encourage applicability and be welcome.

What I mean by this is the facilitation of the opening of a business activity, elimination of bureaucracy, imposement of affordable taxes and tariffs to businesses as well as application of understandable and acceptable penalties to businesses.

Another regard of the administration of work in the fight against fiscal evasion is the very important aspect in the formalization of labor force and real report of salaries received by private sector employees.

Likewise, culture and ethics on implementation of law renders great importance. Sensitization is the most important step in this fight, which requires little effort and produces many outcomes.

Bibliography

[1] Criminal Code of the Republic of Albania

[2] Law No. 9920 "On tax procedures in the Republic of Albania ", as amended

[3] Financa Publike- Harvey S.Rosen, Perkthyer nga:Manjola Kalica,Gentiana Cane, UET Press, 2010

[4] Public Finance and Public Policy - Jonathan Gruber, Massachusetts Institute of Technology,2011

[5] Data on the state budget, INSTAT

[6] Thjeshtimi dhe modernizimi I TVSH ne tregun dixhital te vetem, Departamenti I Politikes, Parlamenti Europian , 2012 (studim I Parlamentit Europian)

[7] Konsolidimi ne anen e te ardhurave dhe strukturat tatimore te rritjes-miqesore:ekonomia evropiane, Gazeta ekonomike, Nr.513, shkurt 2014

[8] Politika e taksave:karakteristika te pergjithshme, Parlamenti Europian 2014

[9] Evazioni fiscal, nje kancer qe vret ekonomine dhe ushqen pabarazine-Dr. Klodian MuÇo prill 2018, Panorama online

[10] Evazioni fiskal dhe ulja e tij ne ekonomine shqiptare-Siela Ibrahimi, Shtator 2013(UAM)

[11] Evazioni fiscal, sa ka qene e sa do te jete-Eduart Zaloshnja, Balkanweb (13 janar 2014)

[12] Korrupsioni dhe tatimpaguesit e pandershem - Eduart Gjokutaj (21 mars 2003)

[13] J.Owens (2013) Politika tatimore ne shekullin e 21: koncepte tre reja per problemet e vjetra globale, programi I qeverisjes, EUI 2013/05 Shtator 2013

[14] Direktiva 2010/24 e Bashkimit Europian

[15] www.tatime.gov.al 